\title{
INTEGRAL INEQUALITIES WITHIN THE FRAMEWORK OF GENERALIZED FRACTIONAL INTEGRALS
}

\section{Paulo M. Guzmán, Juan E. Nápoles Valdés* and Yusif S. Gasimov}

Abstract. In this work, a new generalized fractional integral is defined and studied, and different relationships (equalities and inequalities) are obtained, which have as particular cases several of those reported in the literature. Hermite-Hadamard type inequalities are obtained for different kinds of functions such as symmetric, convex symmetric, Wright-quasi-convex and $h$-symmetrized convex.

Mathematics subject classification (2020): 26D15, 26A51, 32F99, 41A17.

Keywords and phrases: Symmetrized convex function, Hermite-Hadamard type inequality.

\section{REFERENCES}

[1] B. Ahmad, A. Alsaedi, M. Kirane And B. T. Toberek, Hermite-Hadamard, HermiteHadamard-Fejer, Dragomir-Agarwal and Pachpatte Type inequalities for convex functions via new integrals, ArXiv: 1701.00092.

[2] S. Bermudo, P. KóRUS ANd J. E. NÁPOLES V., On q-Hermite-Hadamard inequalities for general convex functions, Acta Math. Hungar. (2020), https://doi.org/10.1007/s10474-020-01025-6.

[3] S. S. Dragomir, Symmetrized convexity and Hermite-Hadamard type inequalities, J. Math. Ineq. 10 (4) (2016) 901-918.

[4] S. S. Dragomir And C. E. M. Pearce, Selected Topics on Hermite-Hadamard Inequalities and Applications, RGMIA Monographs, Victoria University, Melbourne (2000).

[5] A. El Farissi, M. Benbachir and M. Dahmane, An extension of the Hermite-Hadamard inequality for convex symmetrized functions, Real Analysis Exchange 38 (2) (2012) 467-474.

[6] L. FEJÉR, Uberdie Fourierreihen, Math. Naturwise. Anz Ungar. Akad., Wiss 24 (1906) 369-390 (in Hungarian).

[7] J. Galeano Delgado, J. E. Nápoles Valdés and E. Pérez Reyes, A note on some integral inequalities in a generalized framework, Int. J. Appl. Math. Stat., Vol. 60, Issue No. 1, Year 2021, $45-52$.

[8] J. Galeano Delgado, L. E. NÁpoles Valdés and E. PÉRez Reyes, Several integral inequalities for generalized Riemann-Liouville fractional operators, Commun. Fac. Sci. Univ. Ank. Ser. A1 Math. Stat. Volume 70, Number 1, 269-278 (2021), doi:10.31801/cfuasmas.771172.

[9] J. Galeano Delgado, J.E. Nápoles Valdés, E. Pérez Reyes and M. Vivas-Cortez, The Minkowski Inequality for Generalized Fractional Integrals, Appl. Math. Inf. Sci. 15, No. 1, 1-7 (2021), http://dx.doi.org/10.18576/amis/150101.

[10] Y. S. Gasimov, An inverse spectral problem W. R. T. domain, Mathematical Physics, Analysis, Geometry, Vol. 4, No. 3, 2008, pp. 358-370.

[11] Y. S. Gasimov and N. A. Allahverdiyeva, Shape optimization for the eigenfrequency of the plate, Georgian Mathematical Journal, 25 (1), 2018, pp. 19-24.

[12] Y. S. Gasimov, A. Nachaoui And A. A. Niftiyev, Nonlinear eigenvalue problems for pLaplacian, Optimization Letters, No. 4, 2010, pp. 67-84.

[13] P. M. GuZmán AND J. E. NÁPOLEs VAldÉs, Generalized fractional Grüss-type inequalities, Contrib. Math. 2 (2020) 16-21, doi:10.47443/cm.2020.0029. 
[14] J. HADAmARD, Étude sur les propriétés des fonctions entières et en particulier d'une fonction considerée par Riemann, J. Math. Pures Appl. 58, 171-215 (1893).

[15] P. R. Halmos, Measure Theory, D. Van Nostrand Company, Inc., New York, N. Y., 1950.

[16] C. Hermite, Sur deux limites d'une intégrale définie, Mathesis 3, 82 (1883).

[17] I. ISCAN, Hermite-Hadamard-Fejér type inequalities for convex functions via fractional integrals, Stud. Univ. Babe-Bolyai Math. 60 (3) (2015) 355-366.

[18] F. Jarad, E. Ugurlu, T. Abdeljawad And D. Baleanu, On a new class of fractional operators, Advances in Difference Equations (2017) 2017: 247, https://doi.org/0.1186/s13662-017-1306-z.

[19] U. N. Katugampola, New Approach Generalized Fractional Integral, Applied Math and Comp. 218 (2011), 860-865.

[20] M. S. Mitrinovic And I. B. Lackovic, Hermite and convexity, Aequationes Math. 28 (1985) 229-232.

[21] P. O. Монамmed, Inequalities of $(k ; s),(k ; h)$-type for Riemann-Liouville Fractional Integrals, Applied Mathematics E-Notes, 17 (2017), 199-206.

[22] S. Mubeen and G. M. Habibullah, $k$-fractional integrals and applications, Int. J. Contemp. Math. Sci. 7, 89-94 (2012).

[23] J. E. NÁpoles Valdés, F. Rabossi and A. D. Samaniego, Convex functions: Ariadne's thread or Charlotte's spiderweb?, Advanced Mathematical Models \& Applications Vol. 5, No. 2, 2020, pp. 176-191.

[24] J. E. Nápoles, J. M. Rodríguez and J. M. Sigarreta, New Hermite-Hadamard Type Inequalities Involving Non-Conformable Integral Operators, Symmetry 2019, 11, 1108; doi:10.3390/sym11091108.

[25] F. QI AND B. N. GuO, Integral representations and complete monotonicity of remainders of the Binet and Stirling formulas for the gamma function, Rev. R. Acad. Cienc. Exactas Fís. Nat., Ser. A Mat. 111 (2), 425-434 (2017), https://doi.org/10.1007/s13398-016-0302-6.

[26] M. A. NoOR, K. I. NOOR AND S. IFTIKHAR, Integral inequalities for extended harmonic convex functions, Advanced Mathematical Models \& Applications, Vol. 2, No. 3, 2017, pp. 215-228.

[27] E. D. Rainville, Special Functions, Macmillan Co., New York (1960).

[28] R. T. Rockafellar, Lagrange Multipliers and Optimality, SIAM Review, Vol. 35, No. 2 (Jun., 1993), pp. 183-238.

[29] M. Z. Sarikaya, Z. Dahmani, M. E. Kiris And F. Ahmad, $(k, s)$-Riemann-Liouville fractional integral and applications, Hacettepe Journal of Mathematics and Statistics Volume 45 (1) (2016), $77-89$.

[30] E. Set, A. O. Akdemir And E. A. Alan, Some new conformable fractional integral inequalities for symmetrized convex functions, Preprint.

[31] E. SET, A. GozPInAR AND E. A. Alan, Generalized fractional integral inequalities for some classes of symmetrized convex functions, AIP Conf. Proc. 1991 (2018) 020010.

[32] S. Varosanec, On h-convexity, J. Math. Anal. Appl., 326 (2007), 303-311.

[33] Z. H. YANG AND J. F. TIAN, Monotonicity and inequalities for the gamma function, J. Inequal. Appl. 2017, 317 (2017), https://doi.org/10.1186/s13660-017-1591-9.

[34] Z. H. YANG AND J. F. TIAN, Monotonicity and sharp inequalities related to gamma function, J. Math. Inequal. 12 (1), 1-22 (2018), https://doi .org/10.7153/jmi-2018-12-01. 